\title{
En nou bly Skepper, skepsel, skepping - hierdie drie: 'n Teologiese profiel van die ekologiese debat
}

\author{
J Buitendag
}

\begin{abstract}
These three remain. Creator, creature, creation: A theological profile of the ecological debate

In a comprehensive article the author points out that the problem of the relationship between man and nature has become eminent as a result of the ecological crisis. In his search to find a coherence of being, the author presents a state of affairs of the current debate. The solution is being looked for in a pneumatological doctrine of creation which accommodates the quantum physic's concept of time together with that of evolution.
\end{abstract}

Dit is met erkentlikheid teenoor prof dr BJ Engelbrecht dat ek hierdie artikel aan hom opdra. Synde my eertydse leermeester, het ons dikwels oor die teologie besin. Veral die skeppingsleer met sy hedendaagse vraag na die magsprobleem van die natuurwetenskap, het aan die orde gekom. Prof Engelbrecht het 'n besondere fyn aanvoeling vir die werklikheid. Dit is merkwaardig dat hy al in 1949 in sy proefskrif dit betreur het wanneer die geloof in die 'menslike-innerlikheid' begrond word (1949: 72). Hy kritiseer dit wanneer ontologie as 'on-Christelike teologie' afgemaak word (1949: 78). Die volgende uitspraak van hom is juis ook vir ons soeke na 'n werklikheidsverstaan van besondere belang: 'Elkeen kan in sy spreke termini uit die natuur, die natuurwetenskap, die geskiedenis en die filosofie kies, mits hy daarmee nie die heilsfeite waaroor hy spreek, geweld aandoen nie.' (1949: 77). Sy lewe en werk getuig daarom ook sonder uitsondering van sowel 'n credere as 'n intelligere. Sy geloof het nooit die offerande van sy rede gevra nie. In sy studeerkamer hang ook 'n groot foto van Albert Einstein - vir wie hy bewonder. En verstaan.

\section{DIE EKOLOGIESE KRISIS}

Die woord 'ekologie' is vir die eerste keer deur die Duitse bioloog Emst Haeckel in 1866 gebruik. Waar ekologie aanvanklik as 'n onderafdeling 
van die biologie beskou is, is dit tans 'n selfstandige wetenskap. Dit is die wetenskap van die huishouding van die lewe, waar dit om die geheelprentjie van alle bestaan gaan.

Die omgewing wat organismes huisves, staan bekend as ' $n$ biotoop. Dit het altyd bepaalde fisiese, chemiese en biologiese eienskappe en is dus sowel bioties as abioties. Die eenheid wat nou tussen die biotoop en die organismes bestaan, staan bekend as 'n ekostelsel. ' $n$ Legio faktore binne sowel as buite die ekostelsel, bepaal die unieke aard daarvan. Die lewensgemeenskap van die biotoop stel voortdurend bepaalde eise daaraan wat deurslaggewend vir voortbestaan is. Die moontlikheid van oorlewing word dan deur 'n bepaalde spesie se toleransievermoë bepaal. Wanneer sekere omgewingsfaktore hierdie toleransie sou oorbelas, ontstaan die moontlikheid van verswakking of "uitwissing van die bepaalde spesie met sekere implikasies vir die biotoop.

'n Ekostelsel vorm met ander woorde 'n min of meer geslote stelsel van organismes wat deur interaksie 'n dinamiese ewewig na binne en 'n bepaalde stabiliteit na buite handhaaf. Die ekologiese krisis meld hom nou aan wanneer dit versteur word. En die grootste enkele versteurende faktor is onteenseglik bewys as - die mens (Kreeb 1979: $8-67$.

Ter inleiding wil ek volstaan met enkele vry-vertaalde sinne uit die reglement van die Oeko-Institutes in Freiburg:

Die ekologiese krisis is voor die hand liggend: ons is besig om ons aarde te vernietig. Ons vergiftig ons riviere, oseane en ons lug. Ons roei diere en plante uit en verkwis die natuurlike hulpbronne van die aarde. Ons laat aan ons nageslag 'n uitgesuigde en vergiftigde wêreld agter. En nou staan ons uiteraard nie onerkentlik teenoor die rol wat die nywerhede oor eeue heen vir die mensdom beteken het nie. Ons is ook nie onsimpatiek teenoor die miljoene mense wat werksgeleenthede hierdeur vind nie. Maar mens kan jou oë nie daarvoor sluit dat die nywerhede grootliks vir hierdie katastrofe verantwoordelik is nie. Iewers moet halt geroep word. Dit is elke burger se verantwoordelikheid om mee te werk aan 'n menswaardige toekoms vir almal. Ons moet ons nie net afwend van die negatiewe oorsake van die krisis nie, maar ons ook vergewis wat ons onder die positiewe vraag van wat die lewe is, verstaan. Dit gaan dus om alternatiewe vir die toekoms wat slegs bereik sal word deur 'n gemeenskaplike aksie van verskillende wetenskappe binne die universele ekologiese raamwerk. 


\section{2. 'N KLAG TEEN DIE CHRISTENDOM}

Sedert die sestigerjare is ' $n$ stroom van beskuldigings en selfs verwyte teen die adres van die Christendom geslinger. Sommiges het selfs sover gegaan as om die Christendom direk van mede-aanspreeklikheid vir die ekologiese krisis te beskuldig. Dit is algemene kennis in die onderhawige debat dat die Amerikaanse historikus, Lynn White, die eerste persoon was wat hierdie beskuldiging geartikuleer het. Dit het hy in 1967 gedoen met sy publikasie The Historical Roots of our Ecological Crisis. Van die vele geskrifte wat in navolging hiervan die lig gesien het, het veral titels opgeval soos Das Ende der Vorsehung. Die gnadenlosen Folgen des Christentums (Amery 1972) en Umweltkrise - Folge des Christentums? (Krolzik 1979a).

Die bekendste klag teen die Christendom kan ons tipeer as dié van die dominium terrae. 'n Bepaalde verstaan van die mens se kultuuropdrag het volgens die beskuldiging aanleiding gegee tot die mens se uitbuiting van die natuur. Die wetenskap en tegniek van die mens met sy goddelose kontaminasie van moet en kan, het die magtige wapens geword waarmee die mens na hartelus hom harteloos aan die natuur vergryp het.

Aan die ander kant is nie net die Christendom se siening ten opsigte van die natuur gekritiseer nie, maar ook sy siening ten opsigte van die mens, te wete sy begrip van die imago Dei. Op demiurgagtige wyse het die mens nog altyd 'n god-wees oor die aarde gewaan. Die mens word sodoende die Maître et possesseur de la nature.

Hiermee saam sou mens die Christendom se ongeërgdheid ten opsigte van geboortebeperking kon verstaan. Genesis 1: 28 is dikwels so uitgelê dat gemeen is dat die mens die maksimum getal kinders behoort te hê. Die probleem is daarin geleë dat die teologie die menslike voortplanting te lank in die eng kader van die individuele huwelik geplaas het. Die getal mense op aarde het eenvoudig net te veel geword en die beheer daarvan 'n kollektiewe verantwoordelikheid. Dié syfer word ook beïnvloed deur die mens se 'lydingstraagheid', sy onwilligheid om op te offer (Altner 1980: 128, 154). Hy moet sterf, maar wil nie.

\section{DIE REAKSIE VAN DIE CHRISTENDOM}

Die antwoord van die Christendom het nie agterweë gebly nie. Van die bekendste reaksies was dié van Westermann (1974), Lohfink (1977), 
Steck (1978), Liedke (1979), Krolzik (1979a) en ander. Altner het hierdie antwoord die beste verwoord deur te stel dat nie die gehoorsaamheid aan die dominium terrae of die begrip van die imago Dei 'n oorsaak vir die ekokatastrofale gevolge is nie, maar wel ongehoorsaamheid en onbegrip (1974: 32, 71 et passim).

Daar is toegegee dat die natuur volgens die priestergeskrif nie heilig of goddelik is nie en dat die mens dit nie moet dien of aanbid soos in sekere ander godsdienste nie. Die mens staan inderdaad op 'n ander vlak as die nie-menslike skepping. Hy heers oor die skepping. Hy is nie die natuur se broer nie, maar sy heer. Albei skeppingsberigte wys onmiskenbaar daarop dat die mens die spits of sentrum van die skepping is.

" Tog is dit verkeerd om die dominium terrae as 'n gewelddadige, brutale vertrap van die natuur te verstaan. Al is dit die kontekslosse betekenis van kabaš en radāh. Lohfink (1977: 156-171) het daarop gewys dat die begrippe nie los van die posisie van Israel verstaan moet word nie. Die 'onderwerp en heers' van Genesis 1: 28 moet saam met sy pendant, Josua 18: 1 verstaan word - 'Die land was nou onderwerp'. Dit was geen tydlose opdrag nie. Dieselfde geld vir 'wees vrugbaar en vermeerder' van die genoemde teks. Die opdrag word immers deur die seën van God ingelui en het dus positiewe betekenis. Eksodus 1: 7 moet hiermee saam gelees word: 'Die Israeliete was vrugbaar en het vermeerder. Hulle het baie geword, so baie dat die land vol was van hulle'. Steck het bygevoeg dat ons die dominium terrae $(1978: 81,290)$ eerder in terme van 'n voedselgebod moet verstaan en die saak het dus niks met skaamtelose uitbuiting te doen nie.

So is die imago Dei ook geensins as die subsistensie van die mens te verstaan nie, maar as sy eksistensie. Dit word dus eerder Christologies as antropologies verstaan. As beeld verteenwoordig die mens God en as gelykenis reflekteer hy Hom. Dit is ' $n$ indikatief en 'n imperatief. Naas die as is die mens dus ook tot iets geskape. Moltmann wys op die interessante afwisseling van meervoude en enkelvoude in Genesis 1: 26 en 27 en maak die gevolgtrekking dat ons hier 'n chiastiese struktuur het: Wanneer God besluit, is Hy meervoudig, maar wanneer Hy skep, is $\mathrm{Hy}$ enkelvoudig. Die mens word weer enkelvoudig geskep, maar moet meervoudig in terme van man en vrou word (1985: 223-250). Die Imago Dei ontsluit dus 'n bepaalde medekreatuurlikheid wat nie anders as ' $n$ verbondsverhouding verstaan kan word nie. 


\subsection{Etiek}

Dit is opmerklik dat die ekologiese debat van die teologie dan ook primêr eties gehanteer word. Birnbacher (1979), Krolzik (1979b), Ganoczy (1982), Daecke (1983), Altner (1980) en ander, poog almal om 'n bepaalde omgewingsetiek die lig te laat sien. Dit gaan telkens om 'n bepaalde koningsverhouding tussen mens en natuur te vind wat beskrywe en voorskrywe. Udo Krolzik (1979b: 188-194) verklaar dan ook dat nie Genesis 1: 26-28 die basis vir hierdie gesprek moet vorm nie, maar wel Genesis 2: 15.

Albert Schweitzer verdien in hierdie verband met sy beginsel van Ehrfurcht vor dem Leben vermelding. Hieronder verstaan hy 'n grenslose verantwoordelikheid teenoor alle lewe denkbaar. Soveel so dat hy selfs van 'n 'massamoord op bakterieë' kan praat! Dit gaan vir hom om die lewe as sodanig, of soos hy dit formuleer, 'Ich bin leben, das leben will, inmitten von Leben, das leben will' (in Kultur und Ethik, Gesammelte Werke in Fünf Bänden, Bd. 11, 377). Die universele draagkrag van die liefde vorm die élan van hierdie etiek. Tog kom dit nie vry van die sensitiewe innerlikheid van die indiwiduele mens wat die beslissing moet neem nie. Dit verval in 'n subjektiwisme en het geen antwoord vir die verantwoordelikheid van die lewelose werklikheid nie.

Die probleem waarmee ons ten diepste met 'n profane omgewingsetiek sit, is die geweldige hoë abstrakte niveau wat dit veronderstel. Dit word duidelik wanneer ons van die verantwoordelikheid van die mens praat. Verantwoordelikheid is egter primêr 'n partikuliere aangeleentheid. Wie is verantwoordelik vir die bewaring van die omgewing? Die mens. Maar wie is hierdie mens tog wat aangespreek word? Hierdie Übermensch makk die verantwoordelikheid dus hol.

Die appèl op die Christen bring 'n verdere dimensie by. Die verantwoordelikheid teenoor die Skepper moet tot 'n verantwoordelikheid vir die skepping lei. Uitbuiting en vernietiging van die skepping is dus slegs moontlik waar die mens in 'n wanbalans met God lewe. Dit is die sonde wat weier dat die dominium terrae begrens en beperk word deur die imago Dei. Dit gaan dus nie om die natuur as sodanig nie, ook nie om 'n selfstandige verantwoordelikheid daarteenoor nie, maar om 'n sosiale verantwoordelikheid van die mens voor God vir die skepping. Omgewingsbewaring is dan die deurvoering van geloof.

\subsection{Dogmatiek}

Na hierdie voorlopige kennisname van die Christelike optrede teenoor die natuur, beleef mens nietemin steeds ' $n$ bepaalde onafheid ten 
opsigte van die beskuldiging teen die Christendom. Die antwoord word immers nie verkry deur bloot 'n ander optrede nie. Groter samehange en onderlinge koherensie sal ook onder loep moet kom. Die beskuldiging raak nie net die etiek van die kerk nie, maar ook - en juis ook - sy dogmatiek. Die Anders handeln moet immers ook gekonstitueer word deur 'n Anders denken (Altner et al 1978)! Ten diepste het ons dus hier met die teologiese verstaan van die werklikheid te doen. Daarom is die beskuldiging van AMK Müller juis ook die grootste uitdaging in hierdie debat:

Der globalbegriffliche (abendländische) Theologie verfehlt von ihrem Ansatz het die Dimensionen schöpferischen und geschöpflichen Heils, sie ist in letzter Konsequenz in die Irre führend und darum heillos (1985: 12).

Die eis wat die ekologiese debat dus aan die Christelike geloof stel, is om die werklikheid so te beskrywe dat die totale skepping raakgesien moet word. Dit gaan dus daarom dat opnuut na die ontiese verbinding tussen Skepper en skepping gekyk sal moet word. Dit is die hart van die skeppingsleer. Ongelukkig is daar nie altyd behoorlik gedefinieer wat onder creatio verstaan word nie. Dit kan immers sowel op die creatio activa (skeppingsdaad) as op die creatio passiva (skeppingsresultaat) dui. Nou bevredig dit nie om bloot die oorsprong van die skepping te bely nie. Hierdie saak moet meer op die spits gedrywe word deurdat gevra word na die verbinding skepsel: skepping, mens: nie-mens. Steck is waarskynlik die eminentste teoloog van die ekologiese debat wat werklik hiermee gewag gemaak het. Sy boek Welt und Umwelt (1978) is werklik' $n$ sine qua non vir enige teologiese gesprek oor hierdie onderwerp. Dit is 'n onbetwisbare feit dat die nie-menslike skepping nog altyd 'n skandelik verwaarloosde tema in die skeppingsleer was. Karl Barth byvoorbeeld, verklaar eenvoudig dat skeppingsleer bloot antropologie is (1979: 2).

Die stelling kan dus nou gemaak word dat 'n spesifieke verstaan van die werklikheid daartoe gelei het dat die mens sodanig met die natuur omgegaan het dat die ekologiese krisis daaruit ontstaan het.

Die mens se verstaan van die werklikheid het twee basiese fasette, te wete ' $n$ beskrywende en 'n vertolkende. In eersgenoemde word daar altyd gestreef om die werklikheid so objektief moontlik te beskryf. Dit word hoofsaaklik bereik deur persoonlike vooroordele sover moontlik te elimineer en alleen resultate te aanvaar wat op natuurwetenskaplike gronde berus. Die mens vertolk weer wanneer hy interpreteer, same- 
hange aandui en veronderstellings ontwerp. Hierdie aktiwiteit is altyd subjektief. Fritz Buri wil hierdie onderskeiding weergee met die woorde Weltbild en Weltanschauung (Buri, Lochman \& Ott 1976: 40-43). Vir eersgenoemde is ons net relatief verantwoordelik en vir laasgenoemde geheel en al.

Die grens hiertussen is natuurlik nie reglynig aan te dui nie. Vir Trillhaas is 'wêreld' 'n religieuse begrip (1972: 102) en vir Schrey is dit geloof (1955: 24). Dit is juis hier waar die ekologiese debat sy aankopingspunt vind deurdat die onderskeiding tussen wêreldbeeld en wêreldbeskouing nie net baie vaag gesien word nie, maar selfs opgehef word. Hiervan is Müller se werk, Die präparierte Zeit (1972), 'n goeie voorbeeld. Subjek en objek staan dan in 'n komplementêre relasie tot mekaar.

Dit is nodig om vlugtig die werklikheidsverstaan van die verlede na te gaan ten einde te sien hoe 'n wêreldbeeld en wêreldbeskouing tot mekaar gestaan het. In die voor-Kopernikaanse era was tyd en ruimte die koördinate van die mens. Die wêreld was organies beleef en mikrokosmos en makrokosmos het gekorrespondeer. Claudeus Ptolomaeus het egter 'n omwenteling teweeg gebring deur 'n geosentriese beeld te ontwerp waarin die aarde in die middelpunt van alles staan en die son en planete in bane daaromheen wentel. Die heelal was vir hom begrens deur ' $n$ bolvormige sfeer waaraan die hemelliggame gevestig is. Duidelik is die identifikasie van wêreldbeeld en wêrelbeskouing raak te sien. Dit is maar wat ons ook in Genesis 1: 1-2: 4a sien met sy veronderstelde wetenskaplike ondertoon.

Nikolaus Kopernikus (1473-1543) sou 'n radikale verandering laat ontstaan. Die són word nou tereg as die middelpunt van die heelal gesien en die aarde wat self om sy eie as draai, wentel soos ander hemelliggame om die son. Galileo Galilei (1564-1642) het hierop voortgebou. Dit word aanvaar dat hulle hierdie insig eerder as 'n wêreldbeskouing aangebied het deurdat die eer steeds aan God gegee is (Gloege 1965: 278).

Maar dit sou verander. Ironies genoeg het nie die natuurwetenskap die wêreldbeeld van 'n geloof probeer suiwer nie, maar ' $n$ religieuse wêreldfilosofie wat sy wortels in 'n neo-Platonisme terugvind. God word nou of in 'n deïstiese eensaamheid verdryf of tot 'n panteïstiese stuk natuur geneutraliseer. Dit het tot 'n spits gekom deur die werk van Rene Descartes (1596-1650).

Die volgende argumente uit Descartes se Meditationes de prima philosophia (1967) is in hierdie verband van belang. Descartes was op 
soek na die Archimediese wêreldmiddelpunt wat die sekerheid van alles sou waarborg. Maar alvorens dit gevind kon word, moes opruimingswerk eers gedoen word deurdat die eeue-oue gebou van sintuiglike waarneming gesloop moes word. Die aangewese metode hiervoor was die volstrekte twyfel. Die inisiatief om tot die waarheid deur te dring, gaan dus vanuit die mens sélf. Die waarheid is dus geleë in die eensaamheid van die menslike bewussyn: cogito ergo sum. Dit is beslis nie die resultaat van die denke oor die syn nie, maar die onmiddellike selfkennis van die bewussyn wat die denke nie kan negeer nie. Hieruit volg die sekerheid dat slegs waar is wat ek helder en onderskeie kan begryp. Die verinnerliking is egter nie subjektiwisties nie. Die waarheid is meer as die partisipasie daaraan, aangesien dit objektief beleef moet word. Waarheid is met ander woorde vir Descartes noodwendig kwantifiseerbaar. In soverre iets dus matematies uitgedruk kan word, is dit waar en heet dit res extensa. Aangesien dit nou alleen sekerheid by grasie van die denke, res cogitans, verkry, is die taak van die subjek om alle kwaliteite altyd te kwantifiseer.

'n Besliste dualisme van innerlike en uiterlike, subjek en objek, en, helaas, meerdere en mindere, word hieruit gebore. In sy toewyding tot die wêreld word die gees van die mens die draer van die natuurlike lig, vir wie se rasionaliteit geen geheim onoplosbaar is nie. Omdat die individuele denke die waarheid nie resloos omvat nie, het ons hier eerder met die kollektief van denke te doen wat Mildenberger formuleer as die abstrakte dualisme van gees en natuur (1981: 23).

\section{SEKULARISASIE}

Die sekularisasie van die moderne tyd hang uiteraard nóú hiermee saam. As voorbeeld van wat dit vir die werklkheidsverstaan oor die algemeen en vir die ekologiese debat in die besonder het, geld die werk van Friedrich Gogarten (1887-1967). Sekularisasie bepaal vir hom die verhouding tussen geloof en rede, God en wêreld. Dit beteken die wêreld moet wêreld en God moet Gód wees. Enige vermenging hiertussen is juis vir hom die Verhängnis der Neuzeit (1958). Dit bring dan die ónwêreldlikheid van God en die ongoddelikheid van die wêreld teweeg. Twee groothede wat slegs middellik versoen kan word, bestaan nou absoluut. En hier bring Gogarten die antropologie ter sprake as die raakvlak: Der Mensch zwischen Gott und Welt (1952)! Die eksistensie van die gelowige bring God en wêreld bymekaar uit. 
Gogarten vind in sekularisasie dus ' $n$ antwoord op Immanuel Kant se Kritik der reinen Vernunft. ' $n$ Kousale ontologiese samehang tussen God en wêreld, Skepper en skepping bestaan nie in die denke van Gogarten nie.

Met groot nadruk en vele herhaling stel Gogarten dan ook dat die sekularisasie die legitieme vrug van die Christelike geloof is. Alhoewel die proses rasionaal verloop, bly dit die Christelike geloof wat die teuels in die hande van die rede gelê het (1958: 8). Daarom wil Gogarten die prestasies van die natuurwetenskap juis ook as prestasies van die Christelike geloof beskou. Op die voetspoor van Luther wat met sy twee-rykeleer ' $n$ positiewe betekenis aan die mens se dade in die wêreld heg, volg Gogarten dan ook met 'n welluidende ja! vir die wetenskap en tegniek. Sonder enige ander voorbehoude hoegenaamd, behalwe dat die natuurwetenskap net aan sy analitiese metode getrou moet bly (1957: 174), beoordeel hy die ontwikkeling en resultate daarvan as positief. Daarom verwyt hy vir Luther dat hy die huiós van Galasiërs 4: 1 en volgende verse nie met seun vertaal het nie, maar met kind (1958: 32). 'n Kind hoor nooit sy verantwoordelikheid soos die seun wat mondig word en sy erfenis in ontvangs neem nie. Die seun word die heer en eienaar van die wêreld (1957: 52-53). Sy verstand neem nou die leiding en het die opdrag om die aarde te onderwerp en daaroor te heers $(1952: 179,336)$.

Indien 'n mens Gogarten se volstrekte skeiding tussen geloof en rede saamlees met sy trots dat die Christelike geloof die natuurwetenskap vólle mandaat in die wêreld gee en dus die suksesse en roem daarvan deel, verstaan mens die kritiek teen die werklikheidsverstaan van die kerk, naamlik dat hy aandeel aan die ekologiese krisis het.

\section{GEVOLGE}

Sodanige kwantifiserende en dualistiese werklikheidsverstaan het onteenseglik geweldige gevolge. ' $n$ Splytende blik ontstaan wat die ganse werklikheid atomiseer. ' $n$ Reduksie in die verstaan daarvan ontstaan dus. Ons kan dit aantoon in terme van die subjek en die verbinding daartussen (Buitendag 1985: 3-4). Indien die waarheid alleen kwantifiseerbaar uitgedruk kan word, beteken dit dat die res cogitans baie aan liefde, sinlikheid, skoonheid en vryheid inboet. Veral vir die gelowige het hierdie werklikheidsverstaan die gevolg dat hy ten opsigte van sy geloof as 'n soort van 'gnostiese innerlikheid' beleef (Dembowski 1979: 
131). Die geloof word in 'n domein verplant waar geen natuurwetenskap dit kan agterhaal nie. Synsuitsprake word deur waarde-uitsprake vervang. Die ontologie word deur die gnoseologie vervang. Scheffczyk (1982: 6-7) formuleer dit juis as sy grootste klag teen die Protestantse teologie. Die gevolge vir die res extensa is ewe fataal. Alles word immers verdeel, geïsoleer, gerubriseer en gekatalogiseer. Die geheel word in elk geval nie gevind in die somtotaal van die dele nie. Wölfel (1981: 4) wys op die belangrikste gevolg van hierdie reduksie wanneer hy sê dat God hierdeur buite rekening gelaat word. Derdens beteken dit dat die werklikheid gedekontekstualiseer word vanweë die abstrakte opvatting van tyd. Alles word gereduseer in tydlose strukture. Elke unikum word uitgedrywe en die toekoms geostraseer. 'n Verskraling van kennis vind dus plaas.

Die implikasie vir die mens in die besonder is dus geweldig. Die mens moes agterkom dat die wetenskap en tegniek waarmee hy die wêreld wou onderwerp, selfmoordwapens geword het. Die rolle het omgeswaai en die mens het die objek geword. Wetenskap en tegniek het in abstraksie gekonsolideer (Gogarten 1968: 9-11) en vorm so die krisis ágter die krisis: 'n Soort van 'n derde wat eintlik maar regeer. So het hierdie werklikheidsverstaan ' $n$ nuwe siekte vir die mens bygevoeg. Dit was Freud wat gesê het dat Kopernikus die mens 'n kosmologiese siekte gegee het en Darwin weer was verantwoordelik vir die biologiese siekte. Freud het die mens toe die psigologiese siekte laat bykry. Die ekologiese krisis het egter 'n vierde bygevoeg, te wete die kubernetiese siekte. Die mens word gestuur en gerig op 'n manier en 'n plek wat nie sy keuse is nie. Daarom is stres net maar die indiwiduele sy van die ekologiese krisis wat die kollektiewe druk van buite na binne weergee.

Konkluderend kan nou gestel word dat die ekologiese krisis die teologie weer met sy kenteoretiese uitgangspunt gekonfronteer het. Die vraag is dus nie meer wat dit inhou vir ons kennis van God, of vir ons kennis van die mens, of vir ons kennis van die wêreld nie, maar wel wat dit inhou vir ons kennis van die werklikheid. Hierdie begrippe beperk én kompleteer mekaar. Van natuurwetenskaplike kant verklaar Klaus Müller dan ook dat die ekologiese krisis eintlik maar neerkom op 'n waarnemingskrisis (1978: 9). Die probleem kom dus daarby in dat wanneer van die kennende subjek af vertrek word, die geheel nooit oorskou kan word nie; die mens is immers self ook natuur. 


\section{7. 'N DINAMIESE WERKLIKHEIDSVERSTAAN}

Ons sal Karl Heim (1874-1958) altyd daarvoor dankbaar wees dat hy die teologie daarop gewys het dat daar nie so iets soos ' $n$ starre en objektiewe werklikheidsverstaan bestaan nie. Soos geen ander teoloog voor of na hom nie, het Heim met die natuurwetenskap in gesprek getree. Timm (1968: 41) sê dat Einstein so beïndruk met Heim se insig was, dat hy by geleentheid glo gesê dat die Heim een van drie ter wêreld was wat sy relatiwiteitsteorieë verstaan het. Heim het 'n apologetiek ontwerp waarin dit om die koppeling van geloof en rede, skepping en natuur gegaan het. Hy wou die wêreldgeheel op een gemeenskaplike noemer geplaas kry. God se plek in die wêreld moes aangedui word waar Hy nóg panteïsties daarmee vereenselwig nóg deïsties daaruit verdrywe word.

Maar ten einde dit te bereik moet die statiese wêreldbeeld met ' $n$ dinamiese vervang word. Heim wy daarom Band V van sy hoofwerk Der evangelische Glaube und das Denken der Gegenwart (1951) wat in ses volumes verskyn het, in die geheel daaraan ten einde die drie absoluta van die natuurwetenskap, as afgode te ontmasker. Die eerste was dié van die absolute objek. Die ontdekking van die werkingskwantum het die segetog vir 'n dinamiese werklikheid begin. Hierdie was vir Heim die ontdekking der ontdekkings, omdat dit altyd konstant is, maar tog materieloos is. Voeg nou hierby dat die atoomkern 11 gewigseenhede tydens sy verdeling laat verdwyn deurdat dit in energie omgesit word, tesame met die feit dat elektromagnetiese straling aantoon dat energie in die vorm van lig ontsnap, en ' $n$ mens besef dat die werklikheid inderdaad nie staties is nie. Die tweede geloof wat Heim aangetoon het, was die absolute tyd-ruimte. Einstein se besondere (1905) en algemene (1916) relatiwiteitsteorieë het aangetoon dat tydtempo relatief tot die waarnemende subjek staan en dat tyd-ruimte dus relatief is. Laastens het Heim die absolute determinasie as ' $n$ afgod ontmasker. Hierdie insig het Kant se voorwaarde van die a priori net mooi omgedraai en dus die verstandskategorieë geëlimineer wat 'n kousaliteit tot gevolg het wat die toekoms bepaal. Die onbepaalbaarheidsrelasie het egter onder andere aangetoon dat die spronge van die elektrone van een baan na ' $n$ ander altyd willkeurig geskied en dus nie kousaal bepaal kan word nie. Dit alles het vir Heim (1951: 41) net een saak uitgespel: 'Die Welt ist nicht, sie geschieht.'

Benewens hierdie feit dat die werklikheid dinamies begryp moet word, is die interafhanklikheid van die komponente daarvan 'n ewe belangrike gedagte. Eksperimente op 'n spesiale fotografiese skerm het 
getoon dat die lig van elektrone wat as energie vrygestel word, soms as golwe en soms as korpuskels waargeneem word. Die ontdekking is toe gemaak dat hierdie fotone se verskyningsvorm afhanklik van die subjek is. Of sterker gesê, die subjek bepaal die verskyningsvorm van die objek! Hieruit is die begrip komplementariteit vir die werklikheidsverstaan gebore.

Geen werklikheidsverstaan kan vandag meer gekonsipieer word wat nie hierdie twee basiese kenmerke van dinamiek en komplementariteit konstitutief daaraan het nie. An sich bestaan eenvoudig niks meer nie. Die werklikheid is met ander woorde relasioneel in die sin dat dit in die refleksie tussen subjekte, objekte, subjek/objek en objek/subjek geleë is (Müller 1972: 388-404).

\section{8. 'N THEOLOGIA NATURAE}

Die teologieë van Gogarten en Heim is in 'n sekere sin tiperend van die twee uitgangspunte wat ons in die werklikheidsverstaan van die Protestantse teologie van die 20ste eeu aantref (Buitendag 1985: 338-340). Ons kan dit die gnoseologiese en die metafisiese modi noem. Eersgenoemde dink vanuit die mens en laasgenoemde vanuit God. Mens sou ook kon sê dat die gnoseologiese modus die eienskap het dat dit die mens as heer en meester in eie reg beskou en dus ' $n$ infralapsariese trek het, terwyl die metafisiese modus weer die mens eerder as slagoffer van die wêreldproses sien en dus 'n supralapsariese trek openbaar. In albei gevalle het ons met 'n reduksie van die werklikheid te doen wat aan 'n globale verstaan mank gaan. Die Kartiaanse dualisme hou hom tog maar steeds skuil in die teologie! Die gnoseologiese modus laat God in die gees van die gelowige aktualiseer en die metafisiese modus laat geloof ' $n$ bonatuurlike beginsel word; in albei gevalle is daar'n stellingname teenoor die natuur.

Die oplossing vir'n teologie van die natuur moet gesoek word in die moontlikheid om dan nie van binne (skepsel) of van bo (Skepper) te vertrek nie, maar van buite (skepping) af. Dit beteken dat 'n fisiese solidariteit met die kreatuur ervaar word. 'n Pneumatologiese skeppingsleer is die implikasie hiervan.

Die taamlik onlangse boek van Moltmann wat oor die skeppingsleer handel, Gott in der Schöpfung. Oekologische Schöpfungslehre (1985), het juis hierdie pretensie. God is in alles, en alles is in God. En omdat alles op ' $n$ bepaalde eindpunt afstuur, is nie die mens die kroon van die skepping nie, maar die sabbat. God is in die skepping teenwoordig by 
wyse van die šekina. Soos en met God, is die heelal in 'n universele simbiose evoluerend op weg na die ewige sabbat. Dit ontsluit 'n bepaalde skeppingsgemeenskap. Omdat die natuurwetenskap slegs die sienlike (=aarde) natuur ken, benodig dit die teologie se visie van die onsienlike (=hemel) skepping. So word die natuur ingeorden in die geskiedenis èn in die toekoms. Hierdeur oorkom Moltmann enigermate die dualisme van bogenoemde uitgangspunte.

Die probleem met Moltmann is egter dat hy ideologiseer, mitologiseer en spekuleer. Hy vertrek nie by die Bybel nie, maar eindig daarby. Die Bybel lê nie vir hom die Triniteitsleer uit nie, maar is self die uitleg daarvan (1980: 79v). Agter die kanon sien Moltmann 'n ander kanon: Die ewige trinitariese gebeure in God (1980: 109). Teks en uitleg wissel dus rolle! Per L $\phi$ nning (1987: 207-223) stem hiermee saam en meen dat Moltmann té veel op Hegel, Bloch en kabbalistiese tradisies steun.

Dit is seker een van die grootste gevare in die ekologiese debat van die teologie. Daar kan so maklik eerder na filosofiese as na teologiese oplossings gevra word. Olivier (1987: 100-115) moet hiervoor versigtig wees in sy gebruikmaking van Jan Smuts se holistiese visie. Ook Cobb en Griffin oortree met hulle prosesteologiese denke (1979). Selfs Karl Barth se skeppingsleer het hierdie metafisiese uitgangspunt deurdat hy in der waarheid vanaf ' $n$ ontologiese verbondsbeginsel vertrek (Buitendag 1986: 674-695).

Die crux van die uitdaging lê juis daarin om die genoemde dualisme binne 'n openbaringshistoriese horison te oorkom. Dit bevredig nie om die natuurlike kennis van die skepping op te gee, maar dieselfde soort van uitsprake met 'n openbaringsetiket te vervang nie. Dit is ook onder hierdie perspektief dat Wölfel (1981: 20-35) die creatio ex nihilo in die ekologiese debat ter sprake bring. Die ander uiterste van Barth (en Von $\mathrm{Rad}$ ) om skeppingsgeloof in heilsgeloof te laat opgaan, is natuurlik ewe problematies.

Sodanige vervlugtiging van die skeppingsleer in 'n ander locus word meermale in die debat teëgekom. Soos reeds gemeld, is die skeppingsleer vir Karl Barth antropologie (1979: 2). Moltmann sien die ekologiese krisis as die keersy van die sosiale en politieke krisis van ons dag (1977: 136-137). Sölle probeer weer in Lieben und Arbeiten. Eine Theologie der Schöpfung (1985) om 'n skeppingsleer met 'n creatio ex amore daar te stel wat enige androsentrisme besweer. Ganoczy se Theologie der Natur (1982) hanteer die saak weer vanuit Barth se versoeningsleer. Ook Härle en Herms (1979) kan verklaar dat ontologie feitlik 'n regverdigingsleer is. Noack (1979) wil weer graag die estetiek as die substansiële binding 
van die kreatuur onderling sien. Van 'n gnoseologiese fiksasie word duidelik nie weggekom nie.

\section{ONTGINBARE MOONTLIKHEDE}

Met die genoemde basiese kenmerke van 'n eietydse en wetenskaplike werklikheidsverstaan as uitgangspunt, wil ek ten slotte aantoon hoe dit vir die teologie diensbaar gemaak kan word in terme van ons beskouing oor tyd en ewolusie. Die name van Karl Heim, Georg Picht, CF von Weizsäcker en Klaus Müller kan uitgesonder word as eksponente wat werklik moeite gedoen het om die tyd as die basis en raamwerk van 'n werklikheidsverstaan te sien. Alhoewel Heim in sy lewe nie met die ekologiese krisis gekonfronteer was nie, het hy die konsep van tyd besonder bruikbaar vir die teologie gemaak. Aanskoulik beskrywe hy byvoorbeeld die skepping van alles as die produk van tyd (1980: 77).

Tyd was vir hom die prius van alle syn - Dasein ist Zeitsein (1934: 124). Ruimte is net maar die produk van tyd, oftewel tweedegraadse tyd (1980: 77). Hy illustreer dit aan die hand van 'n plat skyf met verskillende kleure in die onderskeie sektore: Hoe vinniger die skyf om sy eie middelpunt tol, hoe vaer word die afsonderlike kleure totdat daar uiteindelik net een kleur oorbly, 'Also je kürzer die Zeit, desto weniger Unterscheidungen' (1980: 53).

Tyd hou dus die moontlikheid in dat dit die eintlike syn ontsluit, of dan, dat dit die moontlike brug tussen gees en natuur kan span. Dit verbind dus geskiedenis (mens voor God) met gebeurtenis (in die natuur) (Müller 1985: 36). Tyd word nie meer in die Newtonse sin van die woord absoluut as ' $n$ soort 'tydlose tyd' wat ' $n$ ewige teenwoordigheid is, beskou nie. Sodanige tyd is immers geslote deurdat dit alles wat nuut is, ontken. Nee, tyd het, of liewers is, die potensiaal van alles. Dit is veel meer as ' $n$ norm waaraan beweging geyk word. Tyd is die beweging van die dinge self, die uitdrukkingsvorm van die syn. Dit is dus nie 'n liniêre suksessie van verlede-hede-toekoms nie, maar 'n netwerk daarvan wat Müller (1978: 143) as volg voorstel en deur Moltmann (1985: 140) herhaal word:

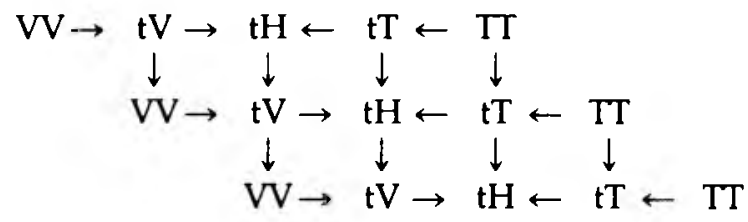

Tens 
Alles word dus vanuit die teenswoordige hede (tH) beleef: Die teenswoordige toekoms $(\mathrm{tT})$ sowel as die teenswoordige verlede $(\mathrm{tV})$. Die vergange verlede (VV) is net so onbereikbaar vir die belewende subjek in sy nou-punt as die toekomende toekoms (TT). 'n Ryke verskeidenheid van ervaringsmoontlikhede word dus deur hierdie tydnetwerk ontsluit.

Kom ons sê dit anders. Tyd is dus nie net die materiaal van alle syn nie, maar ook die horison daarvan. Dit is hier waar die kwantumteorie se komplementariteitsbeginsel ter sprake kom deurdat die werklikheid in die onderlinge verhoudings van subjekte en objekte lê. Tyd is, of liewer word, altyd meervoudig deurdat ervaring of ontmoeting daaruit en daarin ontstaan. Dit is dus vorm en ontmoeting (Müller 1972: 379-404). Wie dus 'God' (vorm) sê, moet 'Vader' (ontmoeting) byvoeg (Müller 1972: 380). Die belewenis van die syn binne die tydsraamwerk maak dit dus vanselfsprekend dat die Gees die vertrekpunt vir ons spreke oor God en werklikheid moet wees.

Hierdie insig is uiteraard van geweldige belang vir ons werklikheidsverstaan. Een ander interessante implikasie hiervan vir die teologie is dat daar nie meer summier van die sin- en diachroniese fases van Bybeleksegese gepraat kan word nie. Waar die geskiedenis staties gestol word, daar is betekenisverlies noodwendig. Tyd is altyd immers relatief tot die waarnemer.

Nou verstaan mens ook waarom die natuur nie ook ter wille van die natuur self bewaar kan word nie. Sin op sigself bestaan nie. Die kwantumteorie vra dat mens verby die refleksielose voorhande syn (vlak 1) sal kom, ja, ook verby die verobjektiveerde fenomene van kousale denke (vlak II) na die geestelike waarneming of begripvolle deelname (vlak III) (Müller 1985: 36-48). Die konvensionele fisika wat iewers tussen die eerste en tweede vlakke is, ken die skepping bloot as 'natuur'. Die nie-objektiveerbare van sy studieveld word dus buite rekening gelaat. Sodanige meta-verskyningsvorme sou ons die sakramentale ervaringsfeer kon noem, wat ongeveer gelyk aan Heim se presenssfeer is. Dis deur hierdie sfeer van die ek waar die ontmoeting met God plaasvind. Dit is die belewenis waar (wanneer!) God Homself meedeel. En hierdie sin is geen ontiese of kategoriale sin nie, maar ' $n$ ontologiese sin van transendentale ervaring (Rahner 1984: 132).

Ook ewolusie vorm 'n sluitsteen vir 'n hedendaagse werklikheidsverstaan. Dit hoef nie te ontstel nie, omdat daar nie net ' $n$ ewolusie van die skepping is nie, maar ook ' $n$ skepping van ewolusie! Daar is immers 'n verskil tussen creatio en creatura. Veral die werk van Karl Rahner en 
Hendricus Berkhof is in hierdie verband besonder bruikbaar. Die ganse werklikheid word binne 'n elevasie-teologie as 'n proses gesien wat op die herskepping uitloop. Werklikheid is dus die kreatiewe ossillasieproses tussen subjekte en objekte en ewolusie die getuienis vir die werklik oop toekoms van God. Getuienis ja, want nie die geskiedenis nie, maar die eskatologie vorm die pendant van die natuur.

Dit is vanselfsprekend dat nie die deterministiese siening van ewolusie ter sprake is nie. Dit was Haeckel en sy dissipels wat hierdie kousaliteit in die gedagtegang van Darwin ingelê het. Charles Darwin het net die teorie geformuleer wat die oorsake van spesieveranderingbeskrywe. Dit is ' $n$ empiriese teorie wat die korrelaat van die vorm in die funksie van 'n lewende spesie sien. Die prinsipes wat hierdie korrelasie bepaal, is dié van erflikheid en seleksie. Naas 'n natuurlike noodwendigheid is daar altyd ook dié van toeval (Jacques Monod). Dit waarborg die subjekskap van seleksie in terme van organiese gemeenskap en topografiese omgewing.

Seleksie word dus duidelik dinamies verstaan. Binne hierdie ewolutiewe werklikheidsverstaan word dan die immanensie van God aangetref. Rahner (1968: 204) oorkom die gees-natuur digotomie boonop deurdat Christus nie bloot mens geword het nie, maar ook materie. God gaan met sodanige verstaan darem nie óp in sy skepping nie. Vergelyk maar die skeppingsberig van die priestergeskrif wat met sy vier kleinerwordende konsentriese sirkels (verse 6-8, 9-12, 20-22 en 24-28) telkens die lewensmilieu van die daaropvolgende skepping aandui. God 'bewoon' dan primêr dit wat buite die periferie lê.

Die punt word hiermee bereik dat dit duidelik is dat die kairologiese begrip van tyd ooreenstem met die ekologiese begrip van ruimte. En dit bring skepping en natuur bymekaar uit.

Ek wil afsluit met die stelling dat lyding die matrys van die lewe is. Deur die lyding word die lewe ontsluit (Johannes 12: 24) asook die eenheid van Skepper, skepsel en skepping (Romeine 8). Lewe en dood is die randstene van ewolusie. Van ons word daarom in hierdie krisis verwag nie net om te lewe nie, maar ook om te sterwe (Psalm 90). Offervaardigheid en lydingskap vervang dan 'n Franciskaanse askese. $\mathrm{Na}$ en uit die weerstand moet ook die berusting volg (Bonhoeffer). Dit is eerbied vir die lewe èn ontsag vir die dood. Die kuns van die Switserse skilder, Ferdinand Hodler, illustreer hierdie gedagte treffend. Dit getuig van 'n deurleefde rousmart na die dood van sy vrou Valentine Godé-Dorel. Enersyds is daar die element van lydingsvolle protes teen haar dodelike siekte en andersyds die element van smart- 
volle berusting in die dood. ' $n$ Doodservaring midde-in sy lewe is uit vertwyfelde weerstand en heroïese aanvaarding gebore. Maar dit was ook 'n lewenservaring midde in sy dood. Hierdie wisselwerking en spanning het gelei tot 'n skeppende impuls vir die toekoms.

Aksie en passie deur lyding verenig, het tot mekaar te staan gekom soos geskiedenis en natuur. Sodoende is ' $n$ nuwe dimensie in die geheimenis van die skepping op die voorgrond gebring. Die geweldige krag wat uit doodservaring resulteer, bring Skepper, skepsel en skepping op dieselfde noemer. Die natuur soos ons hom ken, kan deur ons toedoen tot niet gaan, maar hierdie drie - nooit! Enige uitdrukkingsvorm van die tyd kan tyd nie annuleer nie.

\section{Literatuurverwysings:}

ALTNER, G 1971. Grammatik der Schöpfung: Theologische Inhalte der Biologie. Stuttgart: Kreuz.

ALTNER, G 1974. Schöpfung am Abgrund: Die Theologie vor der Umweltfrage. NeukirchenVluyn: Neukirchener Verlag.

ALTNER, G 1980. Leidenschaft für das Ganze: Zwischen Weltflucht und Macht-barkeitswahn. Stuttgart: Kreuz.

ALTNER, G, BECK, W \& BOSSEL, $\mathrm{H}$ et al 1978. Alternativen: Anders denken - anders handeln. Freiburg: OEKO-Institut. (Textes des Instituts für angewandte Oekologie eV.)

AMERY, C 1972. Das Ende der Vorsehung: Die Gnadenlosen Folgen des Christentums. Hamburg: Rowohlt.

BARTH, K 1979. Die Lehre von der Schöpfung, Bd. 3, Zweiter Teil, in Die Kirchliche Dogmatik. 4. Aufl. Zürich: TVZ.

BIRNBACHER, D 1979. Was kan Verantwortung für die Natur heiszen!, in Klaus, M Meyer-Abich (Hrsg), Frieden mit der Natur, 131-148. Freiburg: Herder.

BUITENDAG, J 1985. Skepping en ekologie: 'n Sistematiese ondersoek na die teologiese verstaan van die werklikheid. DD-proefskrif, Universiteit van Pretoria.

BUITENDAG, J 1986. Die skepping as gelykenis: 'n Beoordeling van die skeppingsleer van Karl Barth in die lig van die appèl van die ekologiese krisis. HTS 42, 674-695.

BURI, F, LOCHMAN, JM \& OTT, H 1976. Schöpfung und Erlösung, in Dogmatik im Dialog, Bd. 3. Gütersloh: Gerd Mohn.

COBB, JB \& GRIFFIN, DR 1979. Prozess-Theologie: Eine einführende Darstellung. Göttingen: Vandenhoeck.

DAECKE, SM 1983. Verantwortung für die Umwelt oder Verehrung der Natur? Zur theologischen Begründung der ökologischen Ethik. Forum Loccum Extra 1, 5-11.

DEMBOWSKI, H 1979. Natur im Gottesfrieden: Erwägungen zur Wahrnehmung von Natur in Theologischer Perspektive, in Klaus, M Meyer-Abich (Hrsg), Frieden mit der Natur, 131-148. Freiburg: Herder.

DESCARTES, R 1967. René Descartes se Bepeinsinge oor die Eerste Filosofie waarin die bestaan van God en die onsterflikheid van die siel bewys word. Vertaal deur DM Kriel. Pretoria: Academica.

ENGELBRECHT, BJ 1949. Die tydsstruktuur in die gedagtekompleks. Hegel-KierkegaardBarth. D Th-proefskrif, Rijksuniversiteit te Groningen.

GANOCZY, A 1982. Theologie der Natur. Zürich: Benziger Verlag.

GLOEGE, G 1965. Heilsgeschehen und Welt, Erster Band. Göttingen: Vandenhoeck. (Theologische Traktate.) 
GOGARTEN, F 1952. Der Mensch zwischen Gott und Welt. Heidelberg: Schneider.

GOGARTEN, F 1957. Die Wirklichkeit des Glaubens: Zum Problem des Subjektivismus in der Theologie. Stuttgart: Friedrich Vorwerk.

GOGARTEN, F 1958. Verhängnis und Hoffnung der Neuzeit: Die Säkularisierung als theologisches Problem. Stuttgart: Friedrich Vorweg.

GOGARTEN, F 1968. Die Frage nach Gott: Eine Vorlesung. Tübingen: Mohr.

HÄRLE, W \& HERMS, E 1979. Rechtfertigung: Das Wirklichkeitsverständnis des christlichen Glaubens. Göttingen: Vandenhoeck. (Uni-Taschenbücher 1016.)

HEIM, K 1934. Gründzüge einer christlichen Lebensanschauung, in Glaube und Denken: Der evangelische Glaube und das Denken der Gegenwart. Berlin: Furche.

HEIM, K 1949. Der christliche Gottesglaube und die Naturwissenschaft, in Glaube und Denken. Der evangelische Glaube und das Denken der Gegenwart. Berlin: Furche.

HEIM, K 1951. Die Wandlung im Naturwissenschaftlichen Weltbild, in Glaube und Denken: Der evangelische Glaube und das Denken der Gegenwart. Berlin: Furche.

HEIM, K 1980. Das Weltbild der Zukunft: Eine Auseinandersetzung zwischen Philosophie, Naturwissenschaft und Theologie. 3. Aufl. Wuppertal: Aussaat.

KREEB, K-H 1979. Oekologie und menschliche Umwelt. Stuttgart: Fischer.

KROLZIK, U 1979a. Umweltkrise - Folge des Christentums? Stuttgart: Kreuz.

KROLZIK, U 1979b. 'Macht Euch die Erde untertan . . .!' und das christliche Arbeitsethos, in Klaus, M Meyer-Abich (Hrsg), Frieden mit de Natur, 131-148. Freiburg: Herder.

LIEDKE, G 1979. Im Bauch des Fisches: Oekologische Theologie. Stuttgart: Kreuz.

LOHFINK, N 1977. Unsere groszen Wörten: Das Alte Testament zu Themen dieser Jahre. Freiburg: Herder.

LøNNING, P 1987. Die Schöpfungstheologie J Moltmanns. Kerygma und Dogma 33/3, 207-224.

MILDENBERGER, F 1981. Geschichte der deutsche evangelische Theologie im 19. und 20. Jahrhundert. Stuttgart: Kohlhammer. (Theologische Wissenschaft Bd 10.)

MOLTMANN, J 1977. Zukunft der Schöpfung: Gesammelte Aufsätze. München: Kaiser.

MOLTMANN, J 1980. Trinität und Reich Gottes: Zur Gotteslehre. München: Kaiser.

MOLTMANN, J 1985. Gott in der Schöpfung: Oekologische Schöpfungslehre. München: Kaiser.

MÜLLER, AMK 1972. Die präparierte Zeit: Der Mensch in der Krise seiner eigenen Zielzetzung. Stuttgart: Radius.

MÜLLER, AMK 1978. Wende der Wahrnehmung: Erwägungen zur Grundlagenkrise in Physik, Medizin. Pädagogik und Theologie. München: Kaiser.

MÜLLER, AMK 1985. Geschöpflichkeitsdefizite in Naturwissenschaft und Theologie, in Müller, AMK, Pasolini, P \& Braun, D, Schöpfungsglaube heute. Neukirchen-Vluyn: Neukirchener Verlag.

NOACK, H 1979. Das Naturschöne als Motiv des Umweltschutzes und der Beitrag des ästhetischen Sinns zur Wahmehmung der Natur, in Klaus M Meyer-Abich (Hrsg), Frieden mit der Natur, 131-148. Freiburg: Herder.

OLIVIER, DF 1987. 'God's rest' the core and Leitmotif of a Christian holistic view of reality?, in Vorster WS, (ed), Are we killing God's earth? Ecology and Theology. Pretoria: UNISA. (Miscellanea Congregalia 30.)

RAHNER, K 1968. Schriften zur Theologie, Band V. Zürich: Benziger Verlag.

RAHNER, K 1984. Grundkurs des Glaubens: Einführung in den Begriff des Christentums. Freiburg: Herder.

SCHEFFCZYK, L 1982. Einführung in die Schöpfungslehre. Darmstadt: Wissenschaftliche Buchgesellschaft.

SCHREY, H-H 1955. Weltbild und Glaube im 20. Jahrhundert. Göttingen: Vandenhoeck.

SÖLLE, D 1985. Lieben und arbeiten: Eine Theologie der Schopfung. Stuttgart: Kreuz.

STECK, OH 1978. Welt und Umwelt. Stuttgart: Kohlhammer. (Biblische Konfrontationen Band 1006.) 
TIMM, H 1968. Glaube und Naturwissenschaft in der Theologie Karl Heims. Berlin: Eckhart. (Glaube und Forschung 23.)

TRILLHAAS W 1972. Religionsphilosophie. Berlyn: De Gruyter.

WHITE, L 1967. The historical roots of our ecological crisis. Science 155, 1203-1207.

WESTERMANN, K 1974. Creation. London: SPCK.

WÖLFEL, E 1981. Welt als Schöfung zu der Fundamentalsätzen der christlichen Schöpfungslehre heute. München: Kaiser. (Theologische Existenz heute.) 